\title{
Protease Production from Biodigested Slurry of Biogas Plants: A Review
}

\author{
Milky Goyal $^{1^{*}}$ and Urmila Gupta Phutela ${ }^{2}$ \\ ${ }^{1}$ Department of Microbiology, Punjab Agricultural University, Punjab, India \\ ${ }^{2}$ School of Renewable Energy Engineering, Punjab Agricultural University, \\ Ludhiana-141004, Punjab, India \\ *Corresponding author
}

\section{A B S T R A C T}

\section{Keywords}

Protease enzyme, Biodigested slurry, Substrate, Biogas, Poultry droppings and Cow dung

Article Info

Accepted:

04 December 2017

Available Online:

10 January 2018
Protease enzymes are the enzymes that hydrolyse proteins. Each type of protease enzyme breaks specific kind of peptide bonds. These enzymes are of great commercial importance contributing to more than $40 \%$ of the world's commercially produced enzymes. Approximately $50 \%$ of the enzymes used in industrial processes are proteolytic enzymes. Different substrates used for the protease enzyme production add to the cost and hence makes the process very costly. Different wastes like wheat bran, rice bran, vegetable waste and sweet potato residue are being explored as substrate to be utilized for enzyme production. However, the present review paper mainly focuses on the biodigested slurry either from cattle dung or poultry droppings based gas plant, which has sufficient nutrients and can be used for protease enzyme production. Poultry dropping and cow dung based biodigested slurry has been used first time as a substrate for protease production which may not only pertains to its value addition but will also cures environmental pollution by managing large amount of slurry discharge from biogas plant.

\section{Introduction}

Enzymes are proteins capable of converting a specific compound (the substrate) into another (product) at a high reaction rate. They are also enantio selective catalysts, which enable them to be used either in the separation of enantiomers from a racemic mixture or in the synthesis of chiral compounds. Although the enzymes utilized today are also found in animals (Chymosin, pepsin, trypsin and pancreatin) and plants (ficin, papain and bromelain), still the bulk of them are of microbial origin (pectinases, glucoamylase, $\alpha$ amylase, among others). As the microorganisms present high growing capability, huge amounts of enzymes can be produced in a short period of time as well as strains can be genetically manipulated, in order to improve their enzyme production capability. Moreover, microbial enzymes are well standardized and marketed by several competing companies.

The market for industrial enzymes was valued at about $\$ 1.5$ billion in 2015. Blind Carbon Copy (BCC) projects this market to grow at a compound annual growth rate (CAGR) of $6.6 \%$ to $\$ 6$ billion by 2016 (Anonymous 2016). In the enzyme industry, three types of 
enzymes are known: Metabolic enzymes (enzymes which our body produces that work in blood, tissues and organs), digestive enzymes (enzymes that break down food into usable material) and food enzymes (enzymes that are contained in raw food). In addition to these, there are some other industrially important enzymes including cellulolytic, lignolytic and proteolytic etc.

The role of enzymes in many processes has been known for a long time. Their existence was associated with the history of ancient Greece where they were using enzymes from microorganisms in baking, brewing, alcohol production and cheese making etc. Thermostable enzymes, which have been isolated mainly from thermophilic organisms, have found a number of commercial applications because of their overall inherent stability (Demirijan et al., 2001). There are 4 main classes of proteases: serine proteases, cysteine proteases, aspartyl proteases and metalloproteases (Erez et al., 2009). On the basis of $\mathrm{pH}$, proteolytic enzymes are classified as acid, alkaline and neutral enzymes (Sheppard et al., 2007).

\section{Production of microbial proteases}

Fermentation is a method of generating enzymes for industrial purposes. It involves the use of microorganisms like bacteria, fungi and yeast to produce the enzymes. Two methods of fermentation have been used to produce enzymes. These are submerged fermentation and solid-state fermentation. Submerged fermentation involves the production of enzymes by microorganisms in a liquid nutrient media. Solid-state fermentation is the cultivation of microorganisms and enzyme production on a solid substrate.

Renge et al., (2012) reported that the SSF uses inexpensive substrates and yields higher volumetric productivity. The isolated fungal culture Aspergillus sps. from soil polluted with abattoir waste secreted extracellular acid proteases in submerged fermentation (Radha et al., 2011). Proteases produced from microorganisms are constitutive or partially inducible in nature. Extracellular protease production in microorganisms is also strongly influenced by media components, e.g. $\mathrm{C} / \mathrm{N}$ ratio, easily metabolizable sugars, such as glucose (Beg et al., 2002) and metal ions. Protease synthesis is also affected by rapidly metabolizable nitrogen sources, such as amino acids in the medium. Besides these, several other physical factors, such as aeration, inoculum density, $\mathrm{pH}$, incubation and temperature also affect the amount of protease produced (Puri et al., 2002). Chemostat cultures have been successfully used for improving protease production for long-term incubations, using a number of microorganisms. Beg et al., (2002) reported that the overall alkaline protease yield from Bacillus mojavensis was improved up to 4fold under semi-batch and fed-batch operations by separating biomass and protease production phases, using intermittent derepression and induction during the growth of the organism.

\section{Fungal proteases}

Fungal proteases magnetized the interest of researches due to high diversity, broad substrate specificity and stability under extreme conditions; it offers an advantage of separation of mycelium by simple filtration. Fungal proteases can conveniently be produced in solid-state fermentation process. Fungal proteases are also used in for modifying food proteins. The different alkaline protease producing fungal species are Aspergillus candidus, Aspergillus flavus, Aspergillus fumigates, Aspergillus melleus, Aspergillus niger, Aspergillus oryzae, Aspergillus sojae, Aspergillus sydowi, 
Cephalosporium sp. KSM 388, Paecilomyces lilacinus, Scedosporium apiospermum Rhizopus oligosporus. (Veloorvalappil et al., 2013)

The enzymes of fungi are largely acid proteases however many fungi have also been reported to produce neutral and alkaline proteases (Tremacoldi et al., 2004). Acid proteases are the most important group of proteases with respect to use in food industry. The acid proteases are low in basic amino acid content and hence have low isoelectric points. However, some strains of Aspergillus niger (Heneri et al., 1988) and Aspergillus flavus also produce alkaline protease (Malathi and Chakraborty, 1991).

\section{Bacterial proteases}

Bacterial alkaline proteases have more commercial importance in laundry, food, leather and silk industries due to their high production capacity and catalytic activity. Bacterial alkaline proteases are characterized by their high activity at alkaline $\mathrm{pH}(8-12)$, with optimal temperature between $50^{\circ} \mathrm{C}$ and $70^{\circ} \mathrm{C}$.

These properties of bacterial alkaline proteases make them suitable for use in the detergent industry. Prominent bacteria producing proteases are Alteromonas sp., Arthrobacter protophormiae, Brevibacterium linens, Hyphomonas jannaschiana VP 3, Lactobacillus helveticus, Microbacterium sp., Nocardiopsis dassonvillei, Oerskovia xanthineolytica TK-1, Pimelobacter sp. 2483, Pseudomonas aeruginosa, Pseudomonas maltophilia, Pseudomonas sp. SJ320, Salinivibrio sp. Strain AF-2004, Staphylothermus marinus, Streptomyces isolate EGS-5, Streptomyces microflavus, Streptomyces moderatus, Streptomyces rectus and Streptomyces rectus var. proteolythicus (Veloorvalappil et al., 2013).

\section{Substrates for proteases production}

Substrates play an important role in production of enzymes using microbial source. A novelty in fermentation medium design is necessary to increase protease enzyme production with low cost solid substrates. Magdi et al., (2009) reported that Bacillus subtilis KO strain was isolated from molasses that was obtained from the industrial products of sugar factory. Different experiments were performed to optimize the cultivation conditions of Bacillus subtilis KO strain and the medium contents to reduce the cost of protease enzyme production. Optimum protease enzyme production of $30-32 \mathrm{IU} / \mathrm{ml}$ was reported after $48 \mathrm{hr}$ incubation period at $40-45^{\circ} \mathrm{C}, \mathrm{pH}$ from $7-7.5,0.1 \%(\mathrm{w} / \mathrm{v})$ gelatin concentration in the presence of ammonium phosphate as inorganic source. Rauf et al., (2010) reported optimal conditions for protease enzyme production using sunflower meal as a substrate with inoculum size of (1\%), at $\mathrm{pH} 3.0$ and incubation temperature of $35^{\circ} \mathrm{C}$ after cultivation period of $72 \mathrm{hr}$. The following table 1 depicts various substrates used for protease production by various researchers.

\section{Biodigested Slurry}

Biogas represents a mixture of different gases produced as a result of the action of different anaerobic microorganism on domestic and agricultural waste (Ezeonu et al., 2005). It usually contains more than $50 \%$ methane and other gases namely carbon dioxide, hydrogen, nitrogen and oxygen in relatively low proportions. The mixture of the gases is combustible if the methane content is more than 50\% (Agunwamba, 2001). Biogas has proven to be a modern energy source that has improved the life of people (Sasse, 1988). In India initially, cowdung or gobar was used as main fermentative material. Thus, these are mostly popular by the name of gobar gas 
plant. Biogas plant consist of mainly two parts: A digestor or fermentative tank with an inlet into which the fermentative mixture (cowdung and water in the ratio of 1:1) is introduced in the form of slurry and a gas holder to collect biogas and helps to cut off air to the digestor with an overflow pipe or outlet chamber to lead out the spent slurry or digested slurry.

\section{Organic matter $+\mathrm{H}_{2} \mathrm{O} \longrightarrow \mathrm{CH}_{4}+$ $\mathrm{CO}_{2}+\mathrm{New}$ biomass $+\mathrm{NH}_{3}+\mathrm{H}_{2} \mathrm{~S}+$ heat}

The organic components of biomass can be classified into broad biological groups: proteins, carbohydrates and lipids or fats. Carbohydrates make up the bulk of the biodegradable material and include cellulose, starch and sugars. Proteins are large complex organic materials composed of hundreds of thousands of amino acid groups. Lipids or fats are materials containing fatty acids. The anaerobic treatment of biomass involves two distinct stages (William, 1999). In the first stage, complex components, including fats, proteins and polysaccharides are hydrolysed and broken down to their component subunits. This is facilitated by facultative and anaerobic bacteria, which then subject the products of hydrolyses to fermentation and other metabolic processes leading to the production of simple organic compounds. This first stage is commonly referred to as acid fermentation. In this stage, organic material is simply converted to organic acids, alcohols and new bacterial cells. The second stage involves the conversion of the hydrolysis products to gases (mainly methane and $\mathrm{CO}_{2}$ ) by several different species of strictly anaerobic bacteria and is referred to as methane fermentation. Anaerobic digestion is a relatively efficient conversion process for poultry dropping producing a collectable biogas mixture with an average methane content of $60 \%$. Systems are usually site specific but must have a certain minimum amount of poultry dropping to supply a given system. The methane produced by this process can be used as a fuel for boilers, as a replacement for natural gas or fuel oil and can also be fired in enginegenerators to produce electricity for on-farm use or sale to electricity companies. Biodigested slurry produced in the plants have various applications particularly for increasing soil fertile.

\section{Poultry droppings}

Kelleher et al., (2002) reported that waste from the poultry industry includes a mixture of excreta (manure), bedding material or dropping (e.g. wood shavings or straw), waste feed, dead birds, broken eggs and feathers removed from poultry houses. Other wastes include those from cage, conveyer belt and water flushing systems. The dropping and manure component of this waste has a high nutritional value and is used as an organic fertiliser, thus recycling nutrients such as nitrogen, phosphorous and potassium. These components (poultry litter) have traditionally been land spread on soil as an amendment. However, over-application of this material can lead to an enriching of water nutrients resulting in eutrophication of water bodies, the spread of pathogens, the production of phytotoxic substances, air pollution and emission of greenhouse gases. Bitzer and Sims, (1988) reported that excessive application of poultry dropping in cropping systems can result in nitrate $\left(\mathrm{NO}_{3}\right)$ contamination of ground water. High levels of $\mathrm{NO}_{3}$ in drinking water can cause methaemoglobinaemia (blue baby syndrome), cancer, and respiratory illness in humans and fetal abortions in livestock. Alternative, environmentally acceptable, disposal routes, with potential financial benefits, may lie in large-scale biomass to energy schemes that can also provide an easier to handle fertiliser as a by-product. Three options have been considered and in some cases implemented: centralised anaerobic digestion, composting and direct combustion with combined heat and 
power. The cost of transporting feedstock has, in all cases, been the limiting factor.

\section{Cow dung}

Bains et al., (1973) investigated principles of treatment of animal slurries. Biological systems are considered more suitable for recycling purposes, minimising the possibilities of added toxic chemical residues entailed in chemical treatment.

Physical treatment cannot meet al.,1 the objectives and is primarily concerned with disposal such as incineration and dumping. The solid removal in pig and cattle dung slurries was $25-30 \%$ at low loading rates and a greater reduction of the order of $40-50 \%$ was obtained in the treatment of poultry slurry. COD reduction of about $60-90 \%$ in the treatment of pig slurry, $75-90 \%$ with cattle slurry \& $50-67 \%$ in poultry slurry was obtained.

The equipment and methods for the solid liquid separation of slurries are now widely used. Rotary screen with press rollers, combined brushed screen, vibrating screen, \& roller press, vacuum filtration and pressure filtration are some of the methods for the treatment of animal slurries. Application of sedimentation principles for the treatment of animal waste slurry is effective. Deans and Evans (1987) examined gamma irradiation as a possible method for treating slurry. The chemical treatment with metal salts and organic polymers for solid liquid separation of animal manure has also been done.

Table 2 summarizes various substrates used for biogas production, thus producing large amount of slurry. This biodigested slurry is a big menace and needs proper management and value addition otherwise causes environmental pollution.
The proximate and chemical composition of Cow dung, poultry dropping and biodigested slurry determined as per the table 3 which shows that biodigested slurry nitrogen content decreased from cow dung and poultry droppings. So, these all analysis show that biodigested slurry it a great substrate for protease production.

\section{Optimization of cultural parameters}

Incubation period, $\mathrm{pH}$, incubation temperature and size of inoculum are important parameters for maximum yield of enzyme varies among various species or even in the same species isolated from various sources. Many workers have reported a broad incubation period ranging from 36 to $96 \mathrm{~h}$ for the maximum yield of protease enzyme by Bacillus strains (Gupta et al., 2002; Olajuyigble and Ajele, 2008).

Initial $\mathrm{pH}$ of the medium required for obtaining maximum production depends not only upon the bacterium but also upon the ingredients of the medium. Maximum alkaline protease production has been reported from different $\mathrm{pH}$ ranges (7-11) by different Bacillus species (Khosravi et al., 2008). Temperature is one of the most critical parameters that have to be controlled in any bioprocess (Chi and Zhao, 2003). Optimum production temperature for different Bacillus species have been reported as, $25^{\circ} \mathrm{C}$ for Bacillus circulans (Jaswal and Kocher, 2007).

\section{Characterization of proteases enzyme}

Usharani and Muthuraj (2009) reported that optimum $\mathrm{pH}$ for enzyme stability found to be 7.0. At $\mathrm{pH} 6.0$ only $63 \%$ of the maximum enzyme activity was obtained, increasing to $87 \%$ at $\mathrm{pH} 7.0$ and the enzyme activity was declined gradually after $\mathrm{pH} 7.0 .100 \%$ of enzyme activity was still detectable at $\mathrm{pH} 7.0$ after $4 \mathrm{~h}$ at $37^{\circ} \mathrm{C}$. 
Table.1 Different substrates used for protease production

\begin{tabular}{|l|}
\hline Sulbstrate \\
\hline Wheat bran \\
\hline Rice bran \\
\hline Waste hair \\
\hline Pigeon Pea \\
\hline Agro waste storage \\
compost \\
\hline Herbivorous dung \\
\hline Rabbit dung \\
\hline Waste water \\
\hline Vegetable waste \\
\hline Sewage sludge \\
\hline
\end{tabular}

\begin{tabular}{|c|c|}
\hline Micro-organisms & References \\
\hline Aspergillus flavus & Muthulakshmi et al., (2011) \\
\hline Rhizopus strains & Sumantha et al., (2006) \\
\hline Paecilomyces lilacinus & Cavello et al., (2012) \\
\hline Bacillus sp. JB 99 & Johnvesly et al., (2002) \\
\hline Bacillus laterosporus-AK1 & Arulmani et al., (2007) \\
\hline Mucor sp. & Alves et al., (2005) \\
\hline Beauveria sp. MTCC 5184 & Shankar et al., (2011) \\
\hline Aspergillus clavatus ES1 & Hajji et al., (2007) \\
\hline Bacillus circulans & Jaswal et al.,(2008) \\
\hline $\begin{array}{l}\text { Geobacillus } \\
\text { caldoproteolyticus, sp. nov }\end{array}$ & Chen et al., (2004) \\
\hline
\end{tabular}

Table.2 Potential Biogas production from various substrates

\begin{tabular}{|c|c|c|c|c|c|}
\hline Substrate & $\begin{array}{l}* \text { HRT } \\
\text { (days) }\end{array}$ & $\begin{array}{l}\text { Solid } \\
\text { concentration } \\
(\%)\end{array}$ & $\begin{array}{l}\text { Temperature } \\
\left({ }^{\circ} \mathrm{C}\right)\end{array}$ & $\begin{array}{l}\text { Biogas yield } \\
\text { added (m3/ Kg } \\
\text { VS*) }\end{array}$ & $\begin{array}{l}\text { Methane } \\
(\%)\end{array}$ \\
\hline Sewage sludge & 25 & 6.0 & 35 & 0.52 & 68 \\
\hline Domestic garbage & 30 & 5.0 & 35 & 0.47 & - \\
\hline Piggery waste & 20 & 6.5 & 35 & 0.43 & 69 \\
\hline Poultry waste & 15 & 6.0 & 35 & 0.50 & 69 \\
\hline Cattle waste & 30 & 10.0 & 35 & 0.30 & 58 \\
\hline Canteen waste & 20 & 10.0 & 35 & 0.60 & 50 \\
\hline $\begin{array}{l}\text { Food market } \\
\text { waste } \\
\end{array}$ & 20 & 4.0 & 35 & 0.75 & 62 \\
\hline $\begin{array}{l}\text { Mango } \\
\text { processing waste }\end{array}$ & 20 & 10.0 & 35 & 0.45 & 52 \\
\hline $\begin{array}{l}\text { Tomato } \\
\text { processing waste }\end{array}$ & 24 & 4.5 & 35 & 0.63 & 65 \\
\hline Lemon waste & 30 & 4.0 & 37 & 0.72 & 53 \\
\hline Citrus waste & 32 & 4.0 & 37 & 0.63 & 62 \\
\hline Banana peel & 25 & 10.0 & 37 & 0.20 & 55 \\
\hline Pineapple waste & 30 & 4.0 & 37 & 0.37 & 60 \\
\hline $\begin{array}{l}\text { Mixed feed of } \\
\text { fruit waste }\end{array}$ & 20 & 4.0 & 37 & 0.62 & 50 \\
\hline
\end{tabular}

*HRT: Hydraulic retention time; VS: Volatile solids (Somayaji, 2005) 
Table.3 Proximate and chemical analysis of dung and biodigested slurry

\begin{tabular}{|c|c|c|c|c|c|}
\hline \multirow{2}{*}{$\begin{array}{l}\text { S. } \\
\text { No }\end{array}$} & \multirow[t]{2}{*}{ Parameters } & \multicolumn{4}{|c|}{ Substrate } \\
\hline & & $\begin{array}{l}\text { Poultry } \\
\text { dropping }\end{array}$ & $\begin{array}{c}\text { Poultry dropping } \\
\text { based Biodigested } \\
\text { slurry }\end{array}$ & Cow Dung & $\begin{array}{l}\text { Cow Dung based } \\
\text { Biodigested } \\
\text { slurry }\end{array}$ \\
\hline 1. & $\mathrm{pH}$ & $6.2 \pm 0.7$ & $8.1 \pm 0.05$ & $6.97 \pm .03$ & $7.12 \pm 0.05$ \\
\hline 2. & $\begin{array}{l}\text { Total Solids (TS\% dry } \\
\text { weight basis) }\end{array}$ & $38.23 \pm 0.40$ & $7.46 \pm 0.70$ & $18.32 \pm 0.22$ & $8.41 \pm 0.23$ \\
\hline 3. & $\begin{array}{c}\text { Volatile Solids (VS\% dry } \\
\text { weight basis) }\end{array}$ & $63.70 \pm 0.76$ & $54.35 \pm 1.32$ & $84.22 \pm 0.20$ & $66.34 \pm 0.25$ \\
\hline 4. & Ash (\% dry weight basis) & $37.82 \pm 1.08$ & $46.41 \pm 1.87$ & $15.31 \pm 0.30$ & $33.03 \pm 0.16$ \\
\hline 5. & $\begin{array}{c}\text { Acid Detergent Fibre } \\
\text { (ADF \%dry weight basis) }\end{array}$ & $16.23 \pm 1.17$ & $41.51 \pm 0.94$ & $46.96 \pm 0.12$ & $55.23 \pm 0.28$ \\
\hline 6. & $\begin{array}{l}\text { Neutral Detergent Fibre } \\
\text { (NDF \% dry weight basis) }\end{array}$ & $33.75 \pm 0.80$ & $37.76 \pm 0.30$ & $64.65 \pm 0.35$ & $56.99 \pm 0.12$ \\
\hline 7. & Cellulose (\%) & $9.33 \pm 0.41$ & $6.09 \pm 0.90$ & $21.16 \pm 0.30$ & $10.26 \pm 0.28$ \\
\hline 8. & Hemicellulose (\%) & $18.48 \pm 0.80$ & $10.07 \pm 0.10$ & $18.05 \pm 0.14$ & $0.79 \pm 0.03$ \\
\hline 9. & Lignin $(\%)$ & $27.49 \pm 0.46$ & $22.31 \pm 1.11$ & $16.43 \pm 0.25$ & $38.01 \pm 0.34$ \\
\hline 10. & Silica (\%) & $1.77 \pm 0.17$ & $2.75 \pm 0.39$ & $5.18 \pm 0.12$ & $16.10 \pm 0.08$ \\
\hline 11. & Nitrogen $(\%)$ & $7.56 \pm 0.85$ & $6.28 \pm 1.05$ & $4.51 \pm 0.03$ & $3.37 \pm 0.04$ \\
\hline 12. & Protein $(\mathrm{mg} / \mathrm{ml})$ & $0.61 \pm 0.85$ & $0.48 \pm 0.09$ & $1.09 \pm 0.03$ & $0.41 \pm 0.02$ \\
\hline
\end{tabular}

(Goyal et al., 2016) (Kaur and Phutela, 2017)

This might be the neutral protease. The optimum temperature of enzyme was $35^{\circ} \mathrm{C}$. Enzyme activity was stable with temperature within the range of $30^{\circ} \mathrm{C}$ to $60^{\circ} \mathrm{C}$.

Kamoun et al., (2008) reported that enzyme was active at temperature from 50 to $75^{\circ} \mathrm{C}$ and had an optimum at $65-70^{\circ} \mathrm{C}$, while activity decreased rapidly above $70^{\circ} \mathrm{C}$. Addition of $2 \mathrm{mM} \mathrm{CaCl} 2$ resulted in a shift in the apparent optimal temperature for activity from $65-70^{\circ} \mathrm{C}$ to $70^{\circ} \mathrm{C}$.

Oseni (2011) reported that protease from Aspergillus flavus, Aspergillus niger, Aspergillus fumigatus showed the highest activity at day $4\left(7.5 \times 10^{-4} \mathrm{U} / \mathrm{ml} / \mathrm{min}\right),(1.97$ x $\left.10^{-3} \mathrm{U} / \mathrm{ml} / \mathrm{min}\right),\left(4.30 \times 10^{-3} \mathrm{U} / \mathrm{ml} / \mathrm{min}\right)$ respectively. Penicillum italicum showed its highest activity at day $3\left(\begin{array}{lllll}1.87 & \text { x } & 10^{-3}\end{array}\right.$
$\mathrm{U} / \mathrm{ml} / \mathrm{min})$ and lowest activity at day $5(8.3 \mathrm{x}$ $\left.10^{-4} \mathrm{U} / \mathrm{ml} / \mathrm{min}\right)$.

\section{Protease enzyme production from biodigested slurry}

Protease enzyme profile of biodigested slurry of poultry dropping based biogas plant was analysed which showed that biodigested slurry has more enzyme activity of $157 \mathrm{U} / \mathrm{g}$ and $163 \mathrm{U} / \mathrm{g}$ by Humicola fuscoatra MTCC 1409 and Aspergillus (T-14) respectively (Goyal et al., 2016).

Protease activity of biodigested slurry of cow dung based biogas plant showed the activity of $64.39 \mathrm{U} / \mathrm{g}$ and $54.37 \mathrm{U} / \mathrm{g}$ in biodigested slurry from Trichoderma harzianum MTCC 792 and Aspergillus (BL4) (Kaur and Phutela, 2017) 


\section{Industrial applications of proteases}

\section{Detergent additives}

Proteases are one of the standard ingredients of all kind of detergents ranging from those used for household laundering to the reagents used for cleaning contact lenses or dentures. The enzymes must be stable at high temperature and $\mathrm{pH}$ and have compatibility with bleaches, surfactants, chelating and oxidizing agents present in the detergents (Oberoi et al., 2001). Alkaline proteases from Bacillus mojavensis (Beg and Gupta, 2003), Bacillus sp. L21 (Tari et al., 2006) and Bacillus licheniformis RP1 (Sellami-Kamoun et al., 2008) have also been reported useful for detergent industry.

\section{Leather tanning}

Proteases are used in the soaking, dehairing and bating stages of preparing skins and hides. The enzymatic treatment destroys undesirable pigments, increases the skin area and thereby clean hide is produced. Bating is traditionally an enzymatic process involving pancreatic proteases. Varela et al., (1997) reported the use of Bacillus subtilis IIQDB32 alkaline protease for unhairing sheeps skin.

\section{Management of industrial and household waste}

Proteases solubilize proteinaceous waste and thus help lower the biological oxygen demand of aquatic systems. The use of keratinolytic protease for food and feed industry waste, for degrading waste keratinous material from poultry refuse (Ichida et al., 2001) and as depilatory agent to remove hair from the drains (Takami et al., 1992) has been reported. A formulation containing proteases from Bacillus subtilis, Bacillus amyloliquefaciens and Streptomyces sp. and a disulfide reducing agent (thioglycolate), that enhances hair degradation and helps in clearing pipes clogged with hair-containing deposits, is currently available in market.

\section{Photographic industry}

Alkaline proteases play a crucial role in the bioprocessing of used X-ray or photographic films for silver recovery. These waste films contain $1.5-2.0 \%$ silver by weight in their gelatin layer, which can be used as a good source of silver for a variety of purposes. Ishikawa et al., (1993) have reported the use of alkaline protease of Bacillus sp. B21-2 for the enzymatic hydrolysis of gelatin layers of $\mathrm{X}$-ray films to release silver particles.

\section{References}

Agunwamba, J. C. 2001. Waste Engineering and Management Tool. Immaculate Publication Limited, Enugu.

Alves, M.H., Campos-Takaki, G.M., Okada, K., Pessoa, I.H.F. and Milanez, A.I. 2005. Detection of extracellular protease in Mucor species. Revista Ibero Americana de Micologia. 22: 114117. http://dx.doi.org/10.1016/S11301406(05)70020-6

Arulmani, M., Aparanjini, K., Vasanthi, K., Arumugam, P., Arivuchelvi, M., and Kalaichelvan, P. 2007. Purification and partial characterization of serine protease from thermostable alkalophilic Bacillus laterosporusAK1. World J Microbiol Biotechnol. 23:475-481.

Bains, S., Evans, M. R., Hissett, R., and Hepherd, R. Q. 1973. Principles of Treatment of animal slurries. Agri Eng. 28: 72-6.

Beg, Q. K., and Gupta, R. 2003. Purifcation and chracterizatiopn of of an oxidantstable, thiol-dependent serine alkaline protease from Bacillus Mojavensis. Enz Microbiol Technol. 32: 
294-304.

Beg, Q. K., Saxena, R. K., and Gupta, R. 2002. Kinetic constants determination for an alkaline protease from Bacillus mojavensis using response surface methodology. Biotechnol Bioeng. 78: 289-95.

Cavello, I. A., Hours, R. A., and Cavalitto, S. F. 2012. Bioprocessing of "Hair Waste" by Paecilomyces lilacinus as a Source of a Bleach-Stable, Alkaline, and Thermostable Keratinase with Potential Application as a Laundry Detergent Additive: Characterization and Wash Performance Analysis. Biotechnol ResInt. doi:10.1155/2012/369308.

Chen, X.G., Stabnikova, O., Tay, J.H., Wang, J.Y., Tay, S.T. 2004. Thermoactive extracellular proteases of Geobacillus caldoproteolyticus, sp. nov., from sewage sludge. Extremophiles. 8(6):489-98.

Chi, Z., and Zhao, S. 2003. Optimization of medium and cultivation conditions for pullulan production by a new pullulan producing yeast. Enz Microbiol Technol. 33: 206-221.

Deans, E. A., and Evans, M.R. 1987. Gamma irradiation of piggery slurry. Biol wastes. 21: 249-256.

Demirijan, D., Moris, V. F., and Cassidy, C. 2001. Enzymes from extremophiles. Curr Opin Chem Boil. 5: 144-51.

Erez, E., Fass, D., and Bibi, E. 2009. How intramembrane proteases bury hydrolytic reactions in the membrane. Nature Publishing Group. 459: 371-378.

Ezeonu, S. O., Dioha, I. J., and Eboatiu, A. N. 2005. Daily biogas production from different wastes and identification of methanogenic bacteria involved. Nig J Solar Energy. 15: 80-85.

Goyal, M., Phutela, U. G., and Jaswal, R. K. 2016. Biodigested slurry of poultry dropping based biogas plant as substrate for protease production using thermophilic fungi Humicola fuscoatra MTCC 1409 and Aspergillus (T-14). Indian J Ecology. 43(2): 408-412.

Gupta, R., Beg, Q. K., and Lorenz, P. 2002. Bacterial alkaline proteases: molecular approaches and industrial applications. Appl Microbiol Biotechnol. 59: 15-32.

Hajji, M., Kanoun, S., Nasri, M., and Gharsallah, N. 2007. Purification and characterization of an alkaline serineprotease produced by a new isolated Aspergillus clavatus ES1. Process Biochem. 42:791-797.

Heneri, P., Chamtal, B., Odile, T., and Aimee, P. 1988. Semi alkaline proteolytic enzyme by Aspergillus niger by using various protein substrates. J Ferment Technol. 66: 380-82.

Ichida, J. M., Krizova, L., LeFevre, C. A., Keener, H. M., Elwell, D. L., and Burtt, J. E. H., 2001. Bacterial inoculum enhances keratin degradation and biofilm formation in poultry compost. $\mathbf{J}$ Microbiol Methods. 47:199-208

Ishikawa, H., Ishimi, K., Sugiura, M., Sowa, A., and Fujiwara, N. 1993. Kinetics and mechanism of enzymatic hydrolysis of gelatin layers of X-ray film and release of silver particles. J Ferment Bioeng. 76:300-305.

Jaswal, R. K., and Kocher, G. S. 2007. Partial characterization of a crude alkaline protease from Bacillus cirulans and its detergent compatibility. The Internet $\mathbf{J}$ Microbiol. 4: 1-9.

Jaswal, R.K., Kocher, G.S., Virk, M.S. 2008. Production of alkaline protease by Bacillus circulans using agricultural residues: a statistical approach. Indian J Biotechnol. 7:356-360.

Johnvesly, B., Manjunath, B. R., and Naik, G. R. 2002. Pigeon pea waste as a novel, inexpensive substrate for production of thermostable alkaline protease from thermoalkaliphilic Bacillus sp. JB-99. Bioressour Technol. 82 (1): 61-64. 
Kamoun, A. S., Haddar, A., Ali, N. E. H., Frikha, B. G., Kanoun, S., and Nasri, 2008. Stability of thrmostable alkaline proteases from Bacillus licheniformis RP1 in commercial solid laundry detergent formulation. Microbiol Res. 163: 299-306.

Kaur, K., and Phutela, U. G. 2017. Proteolytic enzyme production potentialof biodigested slurry from cattle dung based biogas plant. Agric Res J. 54(1):103-107.

Kelleher, B. P., Leahy, J. J., Henihan, A. M., O'Dwyer, T. F., Sutton, D., and Leahy, M. J. 2002. Advances in poultry dropping disposal technology. Bioresour Technol. 83: 27-36.

Khosravi, D. K., Falahatpishe, H. R., and Jalai, M. 2008. Alkaline protease production on date waste by an alkalophillic Bacillus sp. 2-5 isolated from soil. African J Biotechnol. 7: 1536-1542.

Magdi, A. M., Hezayen, F. F., Moustafa, A., and Shabeb, M. S. A. 2009. Production of protease in low-cost medium by Bacillus subtilis $\mathrm{KO}$ strain. Global J Biotechnol Biochem. 4(2): 132-37.

Malathi, S., and Chakraborty, R. 1991. Production of alkaline proteases by a new Aspergillus flavus isolate under solid-substrate fermentation condition for use as a depilation agent. Appl Environ Microbiol. 57:712-16.

Muthulakshmi, C., Gomathi, D., Kumar, D. G., Ravikumar, G., Kalaiselvi, M., and Uma, C. 2011. Production, Purification and Characterization of Protease by Aspergillus flavus under Solid State Fermentation. Jordan J Biological Sci. 4(3): 137-148.

Oberoi, R., Beg, Q. K., Puri, S., Saxena, R. K., and Gupta, R. 2001. Characterization and wash performance analysis of an SDS-resistant alkaline protease from a Bacillus sp. World J
Microbiol Biotechnol. 17: 493-97.

Olajuyigbe, F. M., and Ajele, J. O. 2008. Some properties of extracellular protease from Bacillus licheniformis Lbb1-11 isolated from "iru" a tradionally fermented African locus bean condiment. Global J Biotechnol Biochem. 3: 42-46.

Oseni, O. A. 2011. Production of Microbial Protease from Selected Soil Fungal Isolates. Nig J Biotech. 23: 28 - 34.

Puri, S., Beg, Q. K., and Gupta, R. 2002. Optimization of alkaline protease production from Bacillus sp. using response surface methodology. Curr Microbiol. 44: 286-90.

Radha, S., Nithya, V. J., Babu, R. H. K., Sridevi, A., Prasad, N. B. L., and Narasimha, G. 2012. Medium optimization for acid protease production from Aspergillus sp under solid state fermentation and mathematical modelling of protease activity. J Microbiol Biotechnol Res. 3(2):155-163.

Rauf, A., Irfan, M., Nadeem, M., Ahmed, I., Muhammad, H., and Nasir, I. 2010. Optimization of Growth Conditions for Acidic Protease Production from Rhizopus oligosporus through Solid State Fermentation of Sunflower Meal. Int J Agril Biol Sci. 1:40-43.

Renge, V. C., Khedkar, S. V., Nikita, R., and Nandurkar. 2012. A review: Enzyme synthesis by fermentation method. Sci Rev Chem Commun. 2(4): 585-590.

Sasse, L. 1988. Biogas Plants. GTZ Publications

Sellami-Kamoun, A., Haddar, A., Ali, N. E., Ghorbel-Frikha, B., Kanoun, S., and Nasri, M. 2008. Stability of thermostable alkaline protease from Bacillus licheniformis RP1 in commercial solid laundry detergent formulations. Microbiol Res. 163: 299306. 
Shankar, S., Rao, M., and Laxman, R.S. 2011. Purification and characterization of an alkaline protease by a new strain of Beauveria sp. Process Biochem. 46:579-585.

Sheppard, M. R., Vinay, K., Abul, K. A., and Nelson, F. 2007. Robbins Basic Pathology, 8th Ed.

Somayaji, D., 2005. Methanogenesis from agro-residual residues: potential and prospects. In "Wealth from waste trends and technologies" editors Banwari lal and MRVP Reddy. New Delhi: The Energy and Resources Institute

Sumantha, A., Deepa, P., Sandhya, C., Szakacs, G., Soccol, C. R., and Pandey, A. 2006. Rice bran as a substrate for proteolytic enzyme production. Braz Arch Bio technol. 49(9): 843-851

Takami, H., Nakamura, S., Aono, R., and Horikoshi, K.1992. Degradation of human hair by a thermostable alkaline protease from alkalophilic Bacillus sp. No. AH-101. Biosci Biotechnol Biochem. 56:1667-69.

Tari, C., Genckal, H., and Tokatli, F. 2006. Optimization of growth medium using a statistical approach for the production of alkaline protease from a newly isolated Bacillus sp. L21. Process Biochem. 41: 659-65.

Tremacoldi, C. R., Watanabe, N. K., and Carmona, E. C. 2004. Production of extracellular acid proteases by Aspergillus clavatus. Wld J Microbiol Biotech. 20:639-42.

Usharani, B., and Muthuraj, M. 2009. Production and characterization of protease enzyme from Bacillus laterosporus. Global J Molecular Sci. 4(2): 180-186.

Varela, H., Ferrari, M. D., Belobradjic, L., Vazquez, A., and Loperena, M. L. 1997. Skin unhairing proteases of Bacillus subtilis: production and partial characterization. Biotechnol Lett. 19:755-58.

Veloorvalappil, N. J., Robinson, B. S., Selvanesan, P., Sasidharan, S., Kizhakkepawothail, N. U., Sreedharan, S., Prakasan, P., Moolakkariyil, S. J., and Sailas, B. 2013. Versatility of microbial proteases. Adv Enzyme Res. 1(3): 39-51.

Williams. P. T. 1999.Waste Treatment and Disposal. Wiley, New York.

\section{How to cite this article:}

Milky Goyal and Urmila Gupta Phutela. 2018. Protease Production from Biodigested Slurry of Biogas Plants: A Review. Int.J.Curr.Microbiol.App.Sci. 7(01): 369-379. doi: https://doi.org/10.20546/ijcmas.2018.701.042 